\title{
シリコン微細加エで創るイオンチャネルチップ†
}

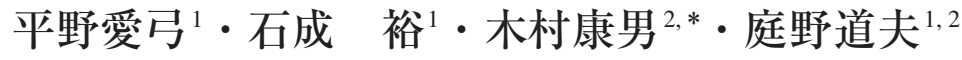 \\ '東北大学大学院医工学研究科 凿 980-8579 宮城県仙台市青葉区荒巻字青葉 6-6 \\ ${ }^{2}$ 東北大学電気通信研究所 函 980-8577 宮城県仙台市青葉区片平 2 丁目 1-1 \\ （2014 年 3 月 25 日受付；2014 年 5 月 15 日掲載決定）
}

\section{Ion-Channel Chips Based on Silicon Microfabrication}

\author{
Ayumi Hirano-Iwata ${ }^{1}$, Yutaka Ishinari ${ }^{1}$, Yasuo Kimura $^{2, *}$ and Michio Niwano ${ }^{1,2}$ \\ ${ }^{1}$ Tohoku University, 6-6 Aoba, Aramaki, Aoba-ku, Sendai, Miyagi 980-8579 \\ ${ }^{2}$ Tohoku University, 2-1-1 Katahira, Aoba-ku, Sendai, Miyagi 980-8577
}

(Received March 25, 2014 ; Accepted May 15, 2014)

\begin{abstract}
In this paper, we will discuss our recent approaches for the formation of mechanically stable artificial bilayer lipid membranes (BLMs) by combining with silicon ( $\mathrm{Si}$ ) micro-fabrication techniques and their application to recording activities of biological channels. BLMs were prepared across microfabricated pores in thin $\mathrm{Si}_{3} \mathrm{~N}_{4}$ septa of Si chips. The edge of the pores was smoothly tapered in nanometer range, which was useful for stabilizing the BLMs suspended in the pores. The BLMs showed a membrane lifetime of $>40 \mathrm{~h}$, tolerance to a high voltage of $\pm 1 \mathrm{~V}$, and tolerance to repetitive solution exchanges. Application to a platform for recording biological channels has been examined by using the human ether-a-go-go-related gene (hERG) potassium channel as an illustrative example. Such stable BLMs with integrated biological channels have the potential for use in a variety of applications, including high-throughput drug screening for various ion-channel proteins.
\end{abstract}

KEYWORDS : lipid bilayer, ion channel, hERG channel, silicon microfabrication, drug screening

\section{1.は じめに}

細胞膜中に存在する種々の膜タンパク質は細胞膜の高 度な物質認識能を担っており, 創薬の重要なターゲット でもある ${ }^{1)}$ 。中でもイオンチャネルは, その名のとお り, 絶縁膜の細胞膜中にイオンの通り道（チャネル）を 形成する機能を持った膜タンパク質であり, 現在の創薬 ターゲットの中で 2 番目に大きい割合を占めている。さ らに近年, 薬物副作用の観点から注目を集めるようにな ったイオンチャネルがある。心筋に多く存在する human ether-a-go-go-related gene (hERG) チャネルである ${ }^{2)} 。 こ$ の hERG チャネルは, 多種多様な医薬品（抗ヒス夕ミン

\footnotetext{
†第 33 回表面科学学術講演会（2013 年 11 月 26 日 28 日）にて発表

E-mail : ahirano@bme.tohoku.ac.jp

*現所属 : 東京工科大学コンピュータサイエンス学部

画 192-0982 東京都八王子市片倉町 1404-1
}

剂, 抗生物質, 胃運動促進薬等) と反応して副作用性の 不整脈を引き起こし, 場合によっては突然死をも誘発す ることから，近年，多くの国で hERG チャネルに対する 臨床試験前の in vitro での副作用評価が義務化され た ${ }^{3,4)}$ 。このような背景を受け, 現在, 創薬の分野にお いて, イオンチャネル電流を記録し評価することの重要 性が高まっている。現在の方法では, 生体膜中のチャネ ル電流を記録するパッチクランプ法が主に用いられてい るが, 全細胞電流を記録するため, 細胞の状態や共存チ ヤネルの影響を受けやすい等の問題点を抱えている。一 方，細胞膜の基本構造である脂質二分子膜を人工的に形 成し，そこに抽出したイオンチャネルタンパク質を包埋 した人工脂質二分子膜再構成系では, 膜および溶液組成 を制御したうえでチャネルへの薬物作用を評価できる系 として，また，単一チャネル電流の記録に適した系とし て再び注目を集めるようになってきている。その結果と して, 多くの研究者がチャネル電流計測の分野に参入 
し，人工脂質二分子膜の研究が再び注目されることとな った。その多くは, 成熟した微細加工技術と脂質二分子 膜形成とを融合することにより，人工脂質二分子膜の課 題であった膜安定性を改善し, 膜形成の再現性や簡便性 を向上させようとするものである ${ }^{5,6)}$ 。本稿では, 半導 体微細加工によって作製したチップ中での膜形成により 人工脂質二分子膜を安定化し，イオンチャネルのチップ 化や薬物スクリーニング系への展開を目指す最近のアプ ローチについて，我々の研究を中心に紹介したい。

\section{2. 半導体微細加工に基づく脂質二分子膜の安 定化}

従来, 人工脂質二分子膜は, テフロン等の絶縁フィル ムに小孔（ $\phi$ 数 数 $100 \mu \mathrm{m} ）$ をあけ, その中での脂質 分子の自己集合によって形成されてきたが，(1)脂質二分 子膜の安定性が低いことと, (2)形成した二分子膜へのイ オンチャネルタンパク質の包埋確率が低いことが課題と なっていた。一方，近年は，微細加工技術と脂質二分子 膜形成とを融合する試みが盛んである ${ }^{6 \sim 8)}$ 。これらの研 究の多くは, 脂質二分子膜の形成場となる小孔を微細加 工技術によって微小化することにより，膜の安定化を目
指すものである。しかし，二分子膜面積の減少はチャネ ルの組込確率の低下にもつながる。したがって，人工脂 質二分子膜に基づくイオンチャネルチップへの応用を考 える場合には，二分子膜の面積を減らすことなく，脂質 二分子膜の安定化を図る必要がある。

膜の微小化とは異なるアプローチとして，筆者らは， 微細孔の縁部と二分子膜との接合部の形状に注目した。 すなわち，滑らかな縁部を持つような微細孔を作製すれ ば，膜保持体と脂質二分子膜の接合部の歪みが減少し て, 膜安定性が向上するのではないかと考え, Fig. 1 a のような縁部構造を持つ微細孔をシリコン $(\mathrm{Si})$ 微細加 工により $\mathrm{Si}_{3} \mathrm{~N}_{4} / \mathrm{Si}$ チップ中に作製し（Fig. $1 \mathrm{c}$ )，その中

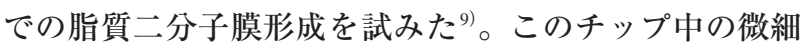
孔は十分な膜面積を保持できる孔径 $(20 \sim 60 \mu \mathrm{m})$ を持 ち, 孔の縁部は $\mathrm{nm}$ スケールでテーパーの付いた滑らか な形状となっている。厚さ 200〜 $240 \mathrm{~nm}$ の $\mathrm{Si}_{3} \mathrm{~N}_{4}$ を積層 した $\mathrm{Si}$ 基板中に, フォトリソグラフィー, ウェットエ ッチングにより微小孔を作製し, 3cyanopropyldimethylchlorosilane（CPDS）で疎水化処理を 行った後, 脂質二分子膜を形成した。脂質二分子膜は, 気一液界面に展開した脂質の単分子膜を微小孔中ではり (a)
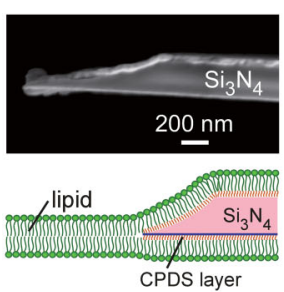

(b)

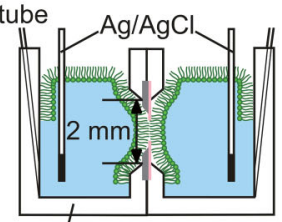

Teflon chamber (c)

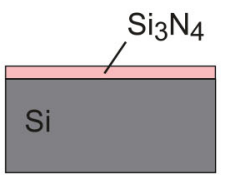

$(2)$
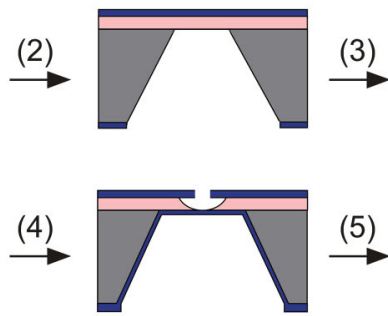

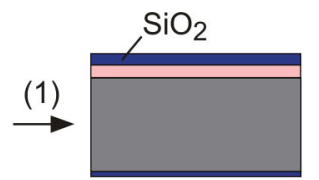

(3)

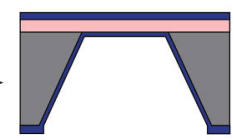

$\stackrel{(5)}{\longrightarrow}$

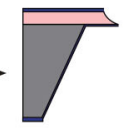

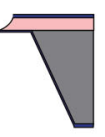

(d)

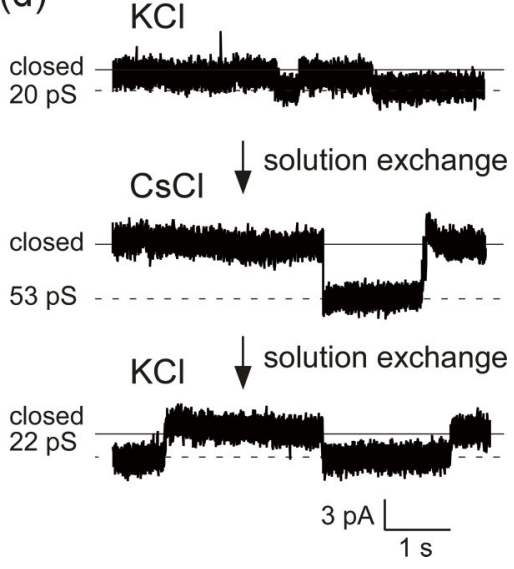

Fig. 1. (color online). (a) (upper) Cross-sectional SEM image of a pore edge. (lower) Schematic of a pore edge which is in contact with a BLM. (b) Schematic of a BLM formed by the monolayer folding method. (c) Procedures for the fabrication of a micropore in a Si chip. ( 1 ) Thermal oxidation and sputtering of $\mathrm{SiO}_{2}$; (2) pattering and anisotropic etching of $\mathrm{Si}$; ( 3 ) sputtering of $\mathrm{SiO}_{2} ;$; 4 ) patterning and isotropic etching of $\mathrm{Si}_{3} \mathrm{~N}_{4}$ and ( 5 ) removal of $\mathrm{SiO}_{2}$ beneath the pore. (d) Examples of single-channel currents recorded from a BLM containing gramicidin channel at an applied potential of $-100 \mathrm{mV}$ when the aqueous solutions surrounding the $\mathrm{BLM}$ were exchanged from $\mathrm{KCl}$ to $\mathrm{CsCl}$ and then back to $\mathrm{KCl}$. The water level was kept higher than the aperture in which the BLM was formed. Low-pass filter : $0.5 \mathrm{kHz}$. "Closed" indicates the current level when the gramicidin channel in the BLM is in a closed state. In $2 \mathrm{M} \mathrm{KCl}$, single-channel current with the conductance level of $\sim 20 \mathrm{pS}$ was observed. After exchanging $2 \mathrm{M} \mathrm{KCl}$ to $2 \mathrm{M} \mathrm{CsCl}$, single-channel currents were still observed with a higher conductance level of $\sim 53 \mathrm{pS}$. The observed conductance levels ( $\sim 20 \mathrm{pS}$ in $2 \mathrm{M} \mathrm{KCl}$ and $\sim 53 \mathrm{pS}$ in $2 \mathrm{M} \mathrm{CsCl}$ ) were very close to reported values for gramicidin in similar recording conditions. ${ }^{10)}$ Changing the aqueous solution back to $2 \mathrm{M} \mathrm{KCl} \mathrm{lead} \mathrm{to} \mathrm{the} \mathrm{observation}$ of channel currents with the single-channel conductance of $\sim 20 \mathrm{pS}$. Adapted with permission from A. Hirano-Iwata et al., Langmuir, 26, 1949 (2010). Copyright 2010 American Chemical Society. Adapted with permission from A. Oshima et al., Micro and Nanosystems, 4, 2 (2012). Copyright 2012 Bentham Science Publishers. 
あわせる方法で形成した（Fig. 1 b)。その結果，90\%を 超える確率 $(\mathrm{n}=53)$ で $\mathrm{G} \Omega$ 以上の膜抵抗を示す脂質二 分子膜が形成された。この二分子膜の安定性は高く, $\pm 1 \mathrm{~V}$ 以上の耐電圧性と寿命 $15 \sim 45$ 時間 $(n=5)$ を示 した。また，薬物スクリーニングへの応用では必須とな る溶液交換耐性も兼社備えており, 同一の膜に対して水 溶液組成を $\mathrm{KCl} \rightarrow \mathrm{CsCl} \rightarrow \mathrm{KCl}$ と交換した際のグラミシジ ンチャネル電流を単一チャネルレベルで記録することに 成功した (Fig. 1 d)。この結果は, イオンチャネルを含 有した状態で複数回の溶液交換に耐える機械的強度の高 い二分子膜系の構築に成功したことを意味する。

\section{3. イオンチャネルアレイヘの展開}

イオンチャネルを対象とする薬物スクリーニング法や 副作用評価法においては, 対象となる候補化合物の数が 膨大になることから，1 度の実験で多サンプルを評価で きるハイスループットな解析系が必要とされる6)。筆者 らは, 多数のチップの同時作製が容易という半導体微細 加工の特徵を活かし, 上述のチップを多数個並列に並べ たイオンチャネルアレイの構築を行った ${ }^{11)}$ 。上述の形成 法では, 脂質二分子膜は垂直に立てられたチップ中で二 つの単分子膜を貼り合わせて形成される。この方法は, 一度に多数の二分子膜を形成できるという長所を持つ が, アレイ測定系への応用を考える場合には, 二分子膜 は水平に配置されている方が望ましい。そこで筆者ら は, はじめに垂直な状態で多数の二分子膜を同時形成
し, その後 90 度回転して水平状の脂質二分子膜アレイ を構築するというアプローチを用いてアレイ化への展開 を試みた（Fig. 2 a)。プロトタイプとして九つの膜の同 時形成を行った結果, 各チップに対して $60 \%$ 以上の確 率で脂質二分子膜を形成することができた。この脂質二 分子膜アレイにモデルチャネルのグラミシジンを包埋し た結果, グラミシジンチャネル電流を複数チップから同 時に測定することに成功した（Fig. 2 b)。

\section{4. hERG チャネルアッセイ系への展開}

微細孔の縁部形状の制御により安定化を達成した脂質 二分子膜であるが，二分子膜とチップの総電気容量が大 きいため, Fig. 1c のようにノイズ電流が大きくなって しまうという課題もあることがわかってきた。また, 大 きな電気容量は過渡応答の要因となるため, 生体于ャネ ルの高速（～ms）な開閉に測定が追随できない可能性 もある。そこで, 作製した $\mathrm{Si}$ チップの $\mathrm{Si}$ 表面部分を $\mathrm{SiO}_{2}$ 熱酸化膜とテフロン層による二種の絶縁層で被覆 することにより膜+チップ全体の総電気容量の抑制を行 った $(\text { Fig. } 3 \mathrm{a})^{12)}$ 。その結果, 総電気容量は, 被覆層な しの場合は $252 \pm 19 \mathrm{pF} （ \mathrm{n}=49 ）$ であったものが, 熱酸 化膜とテフロン層による絶縁層被覆を行った場合は 40 $\pm 4 \mathrm{pF} （ \mathrm{n}=80 ） に$ にで減少し, それに伴いノイズ電流 值も 1 2 pA（ピーク電流幅）（Fig. $3 \mathrm{~b}$ ), 過渡応答を 1 $\mathrm{ms}$ 以下にまで抑制することに成功した。これは, 生体 チャネルの単一チャネル電流記録に適した電気特性であ (a)

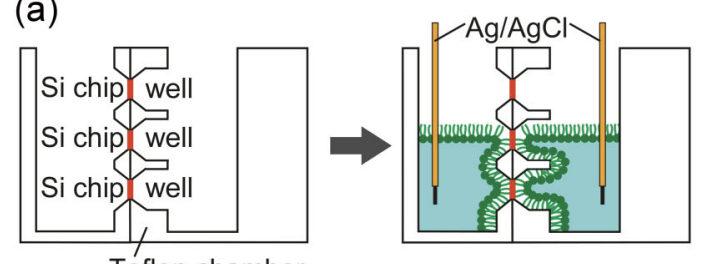

Teflon chamber
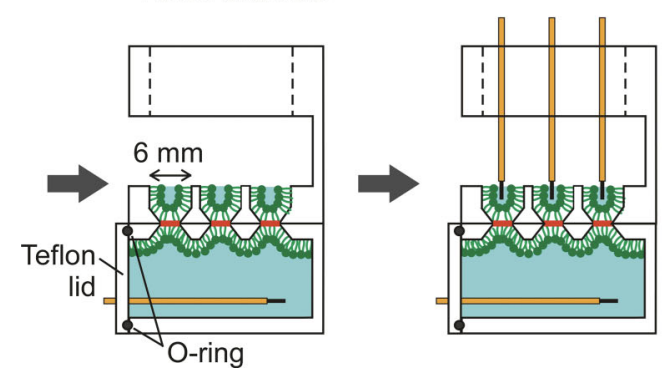

(b)
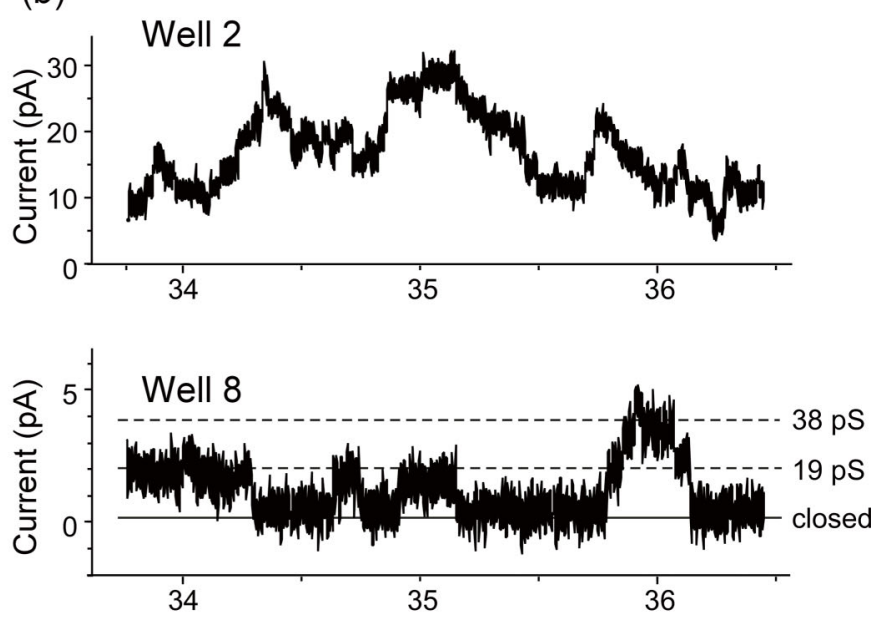

Fig. 2. (color online). (a) Procedures for simultaneous BLM formation and rearrangement of the BLMs into a horizontal array format. (b) Simultaneous current recording from two different BLMs. The applied potential was $+100 \mathrm{mV}$. Low-pass filter : $0.5 \mathrm{kHz}$. At the BLM formed in Well 8, distinct stepwise currents were seen with the single-channel conductance of $\sim 20 \mathrm{pS}$. With a BLM containing multi channels (Well 2), much larger currents with multiple constant steps were observed. No interference or crosstalk was detectable between simultaneously recorded BLMs. Adapted with permission from A. HiranoIwata et al., Appl. Phys. Lett., 101, 023702 (2012). Copyright 2012 American Institute of Physics. 
(a)

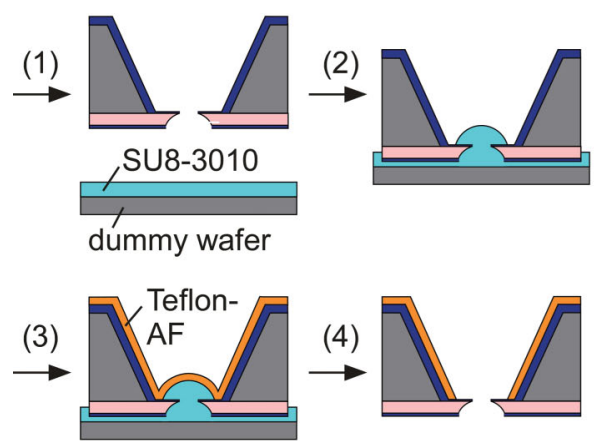

(c)

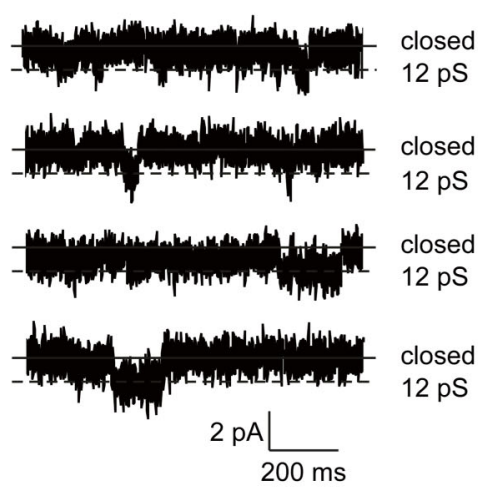

(b)

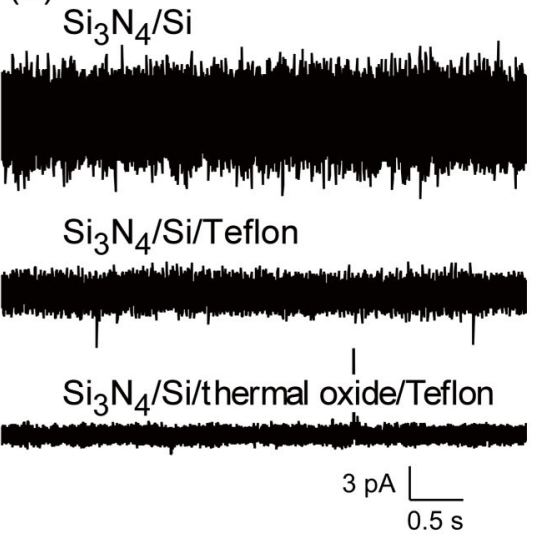

(d)

Control

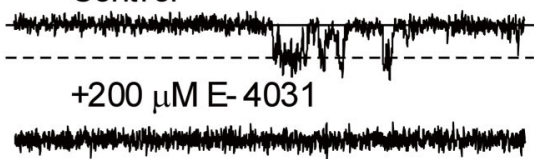

After washout of E-4031

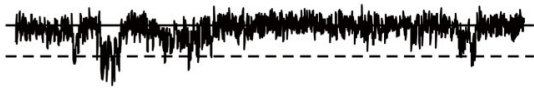

$+100 \mu \mathrm{M}$ astemizole

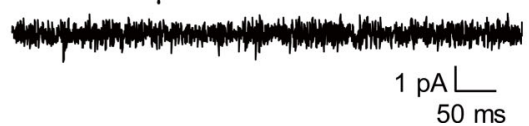

Fig. 3. (color online). (a) Procedures for coating insulator layers : ( 1 ) thermal oxidation; ( 2 ) placing the Si chip on an SU8-3010 layer; ( 3 ) spin coating of Teflon-AF and ( 4 ) lifting off the Teflon-AF layer. (b) Background currents of BLMs formed in Si chips with and without insulator layers. Applied potential : $0 \mathrm{mV}$. Low-pass filter : $1 \mathrm{kHz}$. (c) Single hERG channel currents recorded at an applied potential of $-100 \mathrm{mV}$. Low-pass filter : $0.7 \mathrm{kHz}$. (c) Blocking of a single hERG channel by E-4031 and astemizole. The applied potential was $-100 \mathrm{mV}$. Lowpass filter : $0.7 \mathrm{kHz}$. Adapted with permission from A. Oshima et al., Micro and Nanosystems, 4, 2 (2012). Copyright 2012 Bentham Science Publishers. Adapted with permission from A. Oshima et al., Anal. Chem., 85, 4363 (2013). Copyright 2013 American Chemical Society.

る。

高い膜安定性と，生体チャネル電流測定に適した電気 特性を併せ持つ脂質二分子膜が構築できたので，筆者ら はこの脂質二分子膜への $\mathrm{hERG}$ チャネルの包埋と，その チャネル特性の評価を行った ${ }^{(3)}$ 。hERG チャネルは,こ のチャネルを発現した Chinese hamster ovary（CHO）細 胞から膜画分の状態で抽出し, 絶縁層被覆を行った $\mathrm{Si}$ チップ中で形成した脂質二分子膜に包埋した。その結 果, Fig. $3 \mathrm{c}$ のように hERG チャネルの単一チャネル電 流を記録することに成功した。観測された単一チャネル コンダクタンスは $12 \mathrm{pS}$ であり, 同様の測定条件を用い てパッチクランプ法で観測された報告值 $12 \mathrm{pS}^{14)}$ とよく 一致していた。また, Si チップ中の hERG チャネルは 濃 $\mathrm{K}^{+}$条件において内向き整流性を示したが，この結果
もパッチクランプ法での報告 ${ }^{13)}$ とよく一致していた。さ らに，観測されたチャネル電流は，特異的阻害剤の E4031 ${ }^{15)}$ や，hERG チャネルへの副作用のために使用停止 となった抗ヒスタミン郕のアステミゾール2,4)によって も阻害され (Fig. $3 \mathrm{~d}$ ), 生体膜中と同様の hERG チャネ ルの薬物反応性を $\mathrm{Si}$ チップ中で再現することに成功し た。このような $\mathrm{hERG}$ チャネルに対するブロッカーアッ セイは，溶液交換の可能な膜系において初めて実現可能 であり, 強度の高い人工脂質二分子膜系の構築によりは じめて達成することができた。

\section{5. を と}

微細加工技術と脂質二分子膜形成の融合により, 脂質 二分子膜の安定性は著しく向上した。このような新しい 
脂質二分子膜系においても生体チャネルの活性が保持さ れることが示された今，今後の関心はこれらの安定化脂 質二分子膜に生体チャネルタンパク質をいかに効率よく 包埋し, 高効率スクリーニングのためのイオンチャネル チップとして発展させていくかに焦点が移っていくと思 われる。通常, 生体チャネルタンパク質は脂質二分子膜 リポソームに組み込まれた状態で抽出されるため，この チャネル含有リポソームとチップ中に形成した脂質二分 子膜との膜融合過程の促進がキーになるであろう。昆虫 細胞による膜タンパク質の大量発現系や無細胞タンパク 質合成系の進歩により, 膜タンパク質の操作性が確実に 向上していく今, 微細加工に基づくイオンチャネルチッ プが実現される日も近いと信じている。

\section{文献}

1) J.P. Overington, B. Al-Lazikani and A.L. Hopkins : Nat. Rev. Drug Discovery 5, 993 (2006).

2) M.C. Sanguinetti and M. Tristani-Firouzi : Nature 440, 463 (2006).

3) International Conference on Harmonization of Technical Requirements for Registration of Pharmaceuticals for Human Use. The Non-Clinical Evaluation of the Potential for Delayed Ventricular Repolarization (QT Interval Prolongation) by Human Pharmaceuticals : S7B. (2005).

4) J. Dunlop, M. Bowlby, R. Peri, D. Vasilyev and R. Arias : Nat. Rev. Drug Discovery 7, 358 (2008).

5) 竹内昌治: 表面科学 29, 370 (2008).

6) M. Zagnoni : Lab Chip 12, 1026 (2012).

7) A. Hirano-Iwata, M. Niwano and M. Sugawara: TrAC, Trends Anal. Chem. 27, 512 (2008).

8) P. Kongsuphol, K.B. Fang and Z. Ding : Sens. Actuators, B 185, 530 (2013).

9) A. Hirano-Iwata, K. Aoto, A. Oshima, T. Taira, R. Yamaguchi, Y. Kimura and M. Niwano: Langmuir 26, 1949 (2010).

10) O.S. Andersen : Biophys. J. 41, 119 (1983).

11) A. Hirano-Iwata, T. Nasu, A. Oshima, Y. Kimura and M. Niwano: Appl. Phys. Lett. 101, 023702 (2012).

12) A. Oshima, A. Hirano-Iwata, T. Nasu, Y. Kimura and M. Niwano : Micro and Nanosystems, 4, 2 (2012).

13) A. Oshima, A. Hirano-Iwata, H. Mozumi, Y. Ishinari, Y. Kimura and M. Niwano: Anal. Chem. 85,4363 (2013).

14) A. Zou, M.E. Curran, M.T. Keating and M.C. Sanguinetti : Am. J. Physiol. 272, H1309 (1997).

15) G.X. Liu, J. Zhou, S. Nattel and G. Koren : J. Physiol. 556, 401 (2004). 